\title{
Histidine-Assisted Synthesis and Cellular Compatibility of Magnetic Cobalt Oxide Nanoparticles at Room Temperature
}

\author{
Junjie Zhao $\cdot$ Zhongbing Huang $\cdot$ Jingwen Zeng $\cdot$ \\ Min Deng • Guangfu Yin · Xiaoming Liao • \\ Jianwen Gu
}

Received: 20 August 2011/Accepted: 1 October 2011/Published online: 9 November 2011

(C) The Author(s) 2011. This article is published with open access at Springerlink.com

\begin{abstract}
Magnetic nanoparticles (NPs) of cobalt oxide $\left(\mathrm{Co}_{3} \mathrm{O}_{4}\right)$ with the diameter of $20-40 \mathrm{~nm}$ have been prepared by a simple liquid deposition method in the Histidine (His) assistance at room temperature. Ethanol plays an important role in the preparation of cobalt oxide NPs with a polycrystalline structure. The growth mechanism for $\mathrm{Co}_{3} \mathrm{O}_{4}$ cube particles has been preliminarily explained. The hysteresis loop of NPs reveals their good magnetic property indicating that they can be used in hyperthermia, cell separation etc. These applications need the magnetic particles with cytocompatible properties. The analysis of IR spectrum, TG curve and HRTEM image indicated that cobalt oxide particles was conjugated with the His molecules. Escherichia coli (E. coli) and L929 cells tests suggest a good cellular compatibility at a concentration of less than $0.25 \mathrm{mg} / \mathrm{mL}$, indicating that the prepared $\mathrm{Co}_{3} \mathrm{O}_{4} \mathrm{NPs}$ have a potential for several biomedical applications.
\end{abstract}

Keywords Cobalt oxide - Histidine - Magnetism · Nanoparticles · Cytocompatibility

Electronic supplementary material The online version of this article (doi:10.1007/s10904-011-9611-6) contains supplementary material, which is available to authorized users.

J. Zhao · Z. Huang $(\bowtie) \cdot J$. Zeng $\cdot$ M. Deng $\cdot$ G. Yin $\cdot$ X. Liao College of Materials Science and Engineering, Sichuan University, No. 24, South 1st Section, 1st Ring Road, 610065 Chengdu, Sichuan, People's Republic of China e-mail: zbhuang@yeah.net

J. Gu $(\bowtie)$

The Military General Hospital of Chengdu PLA, Tianhui Town, Chengdu, People's Republic of China

e-mail: gujianwen5000@yahoo.com.cn

\section{Introduction}

Nanotechnology plays a key role in the fields of biomedical engineering [1]. Many magnetic metal or metal oxide nanoparticles (NPs) have a unique superparamagnetic property [2], and the availability of magnetic nanomaterials has inspired us widespread interest for their biological applications such as magnetic resonance imaging (MRI), medical diagnostics, drug delivery, and implantable nanoelectronics etc. [3]. NPs are required to have high biocompatibility [4], dispersion and magnetic response when they are applied in the biomedical fields. Surface modification is an effective method to make them possess good paramagnetic property, protein adsorption and other new physical chemical properties. These magnetic NPs surface can be modified with functional groups, such as $-\mathrm{COOH}$, $-\mathrm{OH},-\mathrm{NH}_{2}$, thus they can be conjugated with active substances, which will be in favour of their application in biochemical and biomedical fields $[5,6]$. Because the final products with above properties were difficult to be obtained through traditional chemical methods, we need to find a new way to prepare magnetic NPs which can be applied in the medical field.

In recent years, a facile aqueous synthesis process at room-temperature has been developed, in which mild reaction conditions, including normal atmospheric pressure, are required, and the natural biomineralization process conditions are mimicked [7]. During this mineralization, the controlled nucleation, growth and aggregation of minerals in the mediation of organic templates lead to specific morphology, orientation and assemblies of the particles [8-10]. DNAs, proteins, peptides, cholesterols, lipids, polysaccharides and amino acid molecules etc., were used as templates for biomorphic mineralization. Biomolecules render facile templates for the fabrication of nanomaterials. A lot of 
biomorphic materials were reported, including metals, metal oxides, and metal sulfides [11]. Danhong Yan et al. [12, 13] prepared olive-like $\mathrm{ZnO}$ particles and single crystalline $\mathrm{GaOOH}$ rods with biocompatibility successfully using silk fibroin (SF) peptide as a template at room temperature. Zhiguo Liu et al. [14] reported a hydrothermal process to prepare single-crystalline gold NPs capped with L-Histidine (His).

Cobalt oxide has a wide range of applications in various industrial fields, for example, rechargeable batteries [15], a catalyst of the abatement of $\mathrm{CO}$ [16], a magnetic material [17] and CO sensors [18]. The spinel tricobalt tetraoxide, $\mathrm{Co}_{3} \mathrm{O}_{4}$, has an energy band-gap of 1.4-1.8 eV [19], which can be used as a $p$-type semiconductor [20], and magnetic materials [21-25]. The distribution of cations on spinel $\mathrm{Co}_{3} \mathrm{O}_{4}$ is shown to be $\mathrm{Co}^{2+}\left[\mathrm{Co}^{3+}\right]_{2} \mathrm{O}_{4}{ }^{2-}$ : the cations inside parentheses are octahedral and those outside are tetrahedrally coordinated with oxygen ions [26]. A various synthesis methods of $\mathrm{Co}_{3} \mathrm{O}_{4}$ have been reported such as sol-gel method, polyol process, solvothermal synthesis, polymer assisted synthesis, thermal decompositions and hydrothermal synthesis [27-33]. Compared with conventional methods of materials production, organic molecules assistance synthesis process is facile, environmentally benign and economic [11], and it has provided inspiration for the controlled formation of this novel inorganic materials. Based on our previous study $[12,13]$ we design to fabricate the magnetic $\mathrm{Co}_{3} \mathrm{O}_{4}$ NPs conjugated with the His molecules on the surface, which may be applied in biomedical fields.

In this paper, we used the His molecules as assistance templates to prepare $\mathrm{Co}_{3} \mathrm{O}_{4} \mathrm{NPs}$, and nanosized $\mathrm{Co}_{3} \mathrm{O}_{4}$ particles are obtained at room temperature. No special conditions such as high temperature, special surfactant, and pressure are required for the reaction. The magnetic properties of the synthesized material were investigated. Moreover, in order to use them in biomedical field, the biocompatibility of the prepared NPs is necessary. The tests for Escherichia coli and L929 cells were carried out, their results suggest were the good biocompatibility of the His- $\mathrm{Co}_{3} \mathrm{O}_{4}$ in the low concentration of NPs suspension. The possible applications in biomedical field could be envisioned, such as cell separation, drug delivery, MRI, hyperthermia [3] etc.

\section{Materials and Methods}

Cobalt nitrate $\left(\mathrm{Co}\left(\mathrm{NO}_{3}\right)_{2} \cdot 6 \mathrm{H}_{2} \mathrm{O}\right)$, sodium hydroxide (anhydrous, 99.96\%) and His are analytical reagent, and deionized water was obtained from our laboratory. Beef extract, peptone and agar were used in the antibacterial tests. The chemical reagents were purchased from Kelong Chemical Co. (Chengdu, China).
A $\quad 0.1 \mathrm{M}$ water-ethanol $(1: 1, \quad \mathrm{v} / \mathrm{v})$ solution of $\mathrm{Co}\left(\mathrm{NO}_{3}\right)_{2} \cdot 6 \mathrm{H}_{2} \mathrm{O}(50 \mathrm{~mL})$ was mixed with histidine of different concentration $(0,0.1,0.3 \mathrm{mg} / \mathrm{mL})$ for $12 \mathrm{~h}$. The control group without His was dissolved in water solvent, and then $0.2 \mathrm{M}$ sodium hydrate $(50 \mathrm{~mL})$ was added drop by drop with continuously stirring at room temperature. The mixture was kept at room temperature for a period of time (1, 5, and 15 days). The precipitate was centrifuged and rinsed 4 times with distilled water and twice with ethanol. Finally, the products were dried at $45^{\circ} \mathrm{C}$ for $24 \mathrm{~h}$.

Although E. coli is a pathogenetic agent of several infective diseases in humans, it has also been used for evaluating the cytotoxicity of NPs due to its sensibility on NPs $[12,34,35]$. Antibacteria tests were carried out by the growth number of $E$. coli on solid agar plates mixed with different concentration of $\mathrm{Co}_{3} \mathrm{O}_{4}$ fluids (from 2.5 to $0.1 \mathrm{mg} / \mathrm{mL}$ ). In the tests, the solid culture medium was prepared containing beef extract $5 \mathrm{mg} / \mathrm{mL}$, peptone $10 \mathrm{mg} / \mathrm{mL}$, sodium chloride $5 \mathrm{mg} / \mathrm{mL}$, and agar powder $20 \mathrm{mg} / \mathrm{mL}$. $\mathrm{Co}_{3} \mathrm{O}_{4} \mathrm{NPs}$ were mixed evenly in liquid medium and were diluted to specific concentration. Bacteria cell strains were cultivated in liquid medium in a shaking incubator at $37^{\circ} \mathrm{C}$ after $4.5 \mathrm{~h}$, and then were diluted $10^{5}$ times. In the experiment, $70 \mu \mathrm{L}$ of bacteria culture fluids and $80 \mu \mathrm{L}$ of $\mathrm{Co}_{3} \mathrm{O}_{4}$ fluids were coated on the surface of solid agar plates. The control group was established without $\mathrm{Co}_{3} \mathrm{O}_{4}$ particles. The plates were incubated at $37^{\circ} \mathrm{C}$ for $24 \mathrm{~h}$, and then the colony counts were taken. All the experiments were conducted in triplicate for each sample.

The cell viability was chosen as a cytotoxicity parameter and determined by the MTT assay, which was applied to evaluate the effect of $\mathrm{Co}_{3} \mathrm{O}_{4}$ particles on $\mathrm{L} 929$ cell viability by measuring the uptake and reduction of tetrazolium salt to an insoluble formazan dye by cellular microsomal enzymes. A total of $200 \mu \mathrm{L}$ of cells was added to 96-well plates (BD Biosciences) at an initial concentration of approximately $2 \times 10^{4}$ cells/well. When the cells reached confluence, $50 \mu \mathrm{L}$ of $\mathrm{Co}_{3} \mathrm{O}_{4}$ suspensions with different concentrations were added and then were cultured at $37{ }^{\circ} \mathrm{C}$. Control cells were incubated in a $\mathrm{Co}_{3} \mathrm{O}_{4}$-free medium. The absorbance of solubilized formazan at $490 \mathrm{~nm}$ was measured with a Microplate Reader 3550 (Bio-Rad). The cell viability was calculated by the following formula: cell viability $(\%)=$ optical density $(\mathrm{OD})$ of the treated cells/OD of the nontreated cells. All of the experiments were performed in triplicate.

The crystal structure of the samples was characterized by $\mathrm{X}$-ray diffraction (XRD, X'Pert, Holand). The morphology of the $\mathrm{Co}_{3} \mathrm{O}_{4}$ particles was observed by transmission electron microscopy (TEM, JEOL-200, $160 \mathrm{kV}$, Japan, high resolution HRTEM, JEOL-2000, $200 \mathrm{kV}$, Japan) and scan electron microscopy (SEM, JEOL-5900LV, 20 kV). Fourier transform infrared (FT-IR) spectrum was recorded by an IR 
Prestige-21 spectrometer. Thermogravimetry (TG) was carried out with a TG/SDTA851 ${ }^{\mathrm{e}}$ analyzer from METTLERTOLEDO Co. of Switzerland. The interaction of histidine and cobalt (II) was detected by UV-Vis spectroscopy techniques. Sample for magnetic measurements was investigated by vibrating sample magnetometer (VSM, Lake shore-7400, USA).

\section{Results and Discussion}

The phase identification of all samples was performed by XRD. The patterns of samples obtained in water with $0,0.1$ and $0.3 \mathrm{mg} / \mathrm{mL}$ His are shown in Fig. $1 \mathrm{a}, \mathrm{b}$ and c, suggesting a rhombohedral phase of $\mathrm{Co}(\mathrm{OH})_{2}$ (JCPDS 30-0443). It is clear that the intensity of $\mathrm{Co}(\mathrm{OH})_{2}$ phase is decreased and the phase is changed from $\mathrm{Co}(\mathrm{OH})_{2}$ to $\mathrm{Co}_{3} \mathrm{O}_{4}$ with the increase of His concentration. Another phase of a composite structure $\mathrm{Co}_{5}\left(\mathrm{O}_{9.48} \mathrm{H}_{8.52}\right) \mathrm{NO}_{3}$ (JCPDS 46-0605) indicates that $\mathrm{NO}_{3}{ }^{-}$enters into $\mathrm{Co}(\mathrm{OH})_{2}$ crystal. Pure $\mathrm{Co}_{3} \mathrm{O}_{4}$ phase (JCPDS 74-1656) can be observed in Fig. 1c pattern of the sample obtained in water-ethanol (1:1) solvent with $0.3 \mathrm{mg} / \mathrm{mL}$ His. It is clear that the crystal has a cubic face centered structure with lattice constant $a=8.084 \AA$. Obviously, the water-ethanol mixed solvent and $\mathrm{His}$ are necessary for the formation of $\mathrm{Co}_{3} \mathrm{O}_{4}$ particles.

TEM image of pure $\mathrm{Co}_{3} \mathrm{O}_{4}$ particles is shown in Fig. 2a, indicating that the size distribution is from 20 to $60 \mathrm{~nm}$. TEM and SEM images of $\mathrm{Co}_{3} \mathrm{O}_{4}$ particles synthesized by His assisted precipitation in water-ethanol (1:1) solvent are shown in Fig. $2 b$ and c. Many cubic NPs with a diameter distribution of $20-40 \mathrm{~nm}$ can be observed, and some NPs

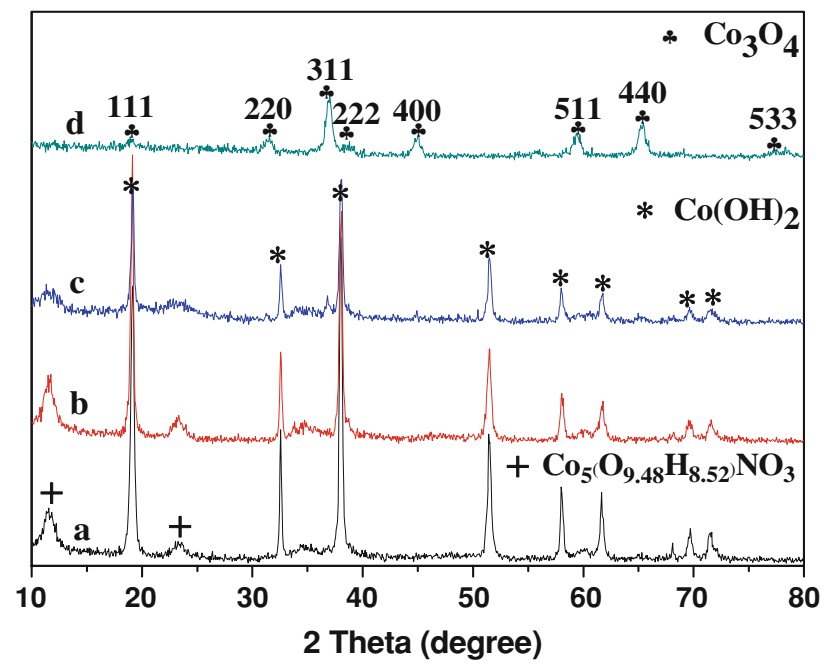

Fig. 1 XRD patterns of crystal produced $\mathbf{a}$ in water with no His, $\mathbf{b}$ in water with $0.1 \mathrm{mg} / \mathrm{mL}$ His, $\mathbf{c}$ in water with $0.3 \mathrm{mg} / \mathrm{mL}$ His, $\mathbf{d}$ in water-ethanol (1:1) mixed solvent with $0.3 \mathrm{mg} / \mathrm{mL}$ His
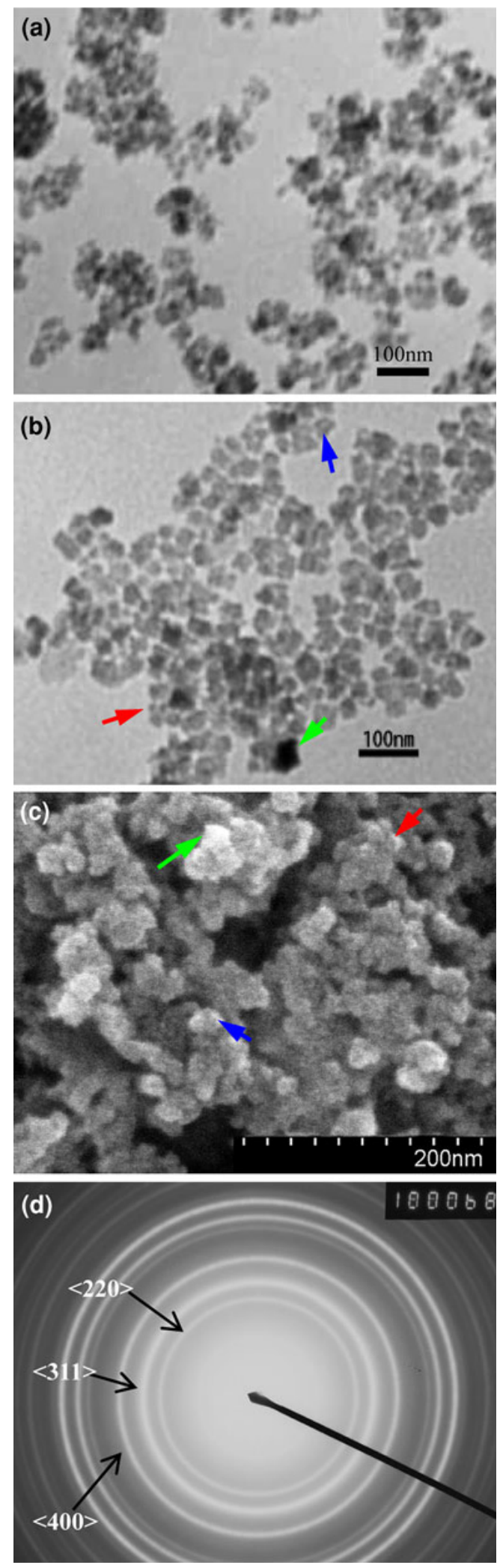

Fig. 2 a TEM image of pure $\mathrm{Co}_{3} \mathrm{O}_{4}$ particles. b TEM and c SEM images of $\mathrm{Co}_{3} \mathrm{O}_{4}$ particles synthesized by His direct precipitation in water-ethanol (1:1) mixed solvent. d The electron diffraction pattern of His- $\mathrm{Co}_{3} \mathrm{O}_{4}$ 
are composed of two or more primary cubic crystals with diameter of $20 \mathrm{~nm}$ (shown by red arrow in Fig. 2b, c). The larger crystalline with diameter of about $40 \mathrm{~nm}$ (shown by green arrow) have grown through the aggregation and fusion of several primary cube particles. Furthermore, some defective crystals similar to hollow structure were also observed (shown by blue arrow). Compared with the shapes of pure $\mathrm{Co}_{3} \mathrm{O}_{4}$ NPs, the His- $\mathrm{Co}_{3} \mathrm{O}_{4}$ NPs are more regular. The electron diffraction pattern in Fig. $2 d$ shows a good polycrystalline structure in nature. According to the calculated results, the (220), (311) and (440) diffraction planes of cubic $\mathrm{Co}_{3} \mathrm{O}_{4}$ are in good agreement with the XRD data.

Figure 3 shows the thermogravimetry curve of His$\mathrm{Co}_{3} \mathrm{O}_{4}$ NPs in the temperature range of $20-400{ }^{\circ} \mathrm{C}$. It is obvious that there are two main weight loss processes. About $5.88 \%$ weight loss between 50 and $110^{\circ} \mathrm{C}$ is attributed to the release of absorbed water in NPs, and the weight loss reached $9.23 \%$ when the NPs were calcined over $230{ }^{\circ} \mathrm{C}$, which is assigned to the thermal decomposition of His molecules and nitrate groups in layered structure. The thickness of coverage layer is about $2-4 \mathrm{~nm}$ after the calculation (the process is shown in supplementary material).

For a better understanding of His- $\mathrm{Co}_{3} \mathrm{O}_{4}$ crystal structures, HRTEM observation was carried out. The HRTEM image in Fig. 4 shows that the interplanar space is $2.43 \AA$, corresponding to the (311) crystal plane of $\mathrm{Co}_{3} \mathrm{O}_{4}$. In addition, the $\mathrm{Co}_{3} \mathrm{O}_{4} \mathrm{NP}$ is covered with a thin layer of amorphous coating (marked with the black arrow), indicating that the His molecules have incorporated onto primary $\mathrm{Co}_{3} \mathrm{O}_{4}$ NPs during the synthesis process.

The functional groups of His- $\mathrm{Co}_{3} \mathrm{O}_{4} \mathrm{NPs}$ were analyzed by FT-IR spectroscopy. Figure 5 show several visible IR absorption bands for $\mathrm{Co}_{3} \mathrm{O}_{4} \mathrm{NPs}$, $\mathrm{His}_{-} \mathrm{Co}_{3} \mathrm{O}_{4} \mathrm{NPs}$ and His. The pure $\mathrm{Co}_{3} \mathrm{O}_{4}$ NPs was prepared after sintering from His$\mathrm{Co}_{3} \mathrm{O}_{4} \mathrm{NPs}$ for $2 \mathrm{~h}$ at $400{ }^{\circ} \mathrm{C}$. In curve $a$ and $b$, the bands located at 570 and $663 \mathrm{~cm}^{-1}$ are assigned to $\mathrm{Co}-\mathrm{O}$ bond of

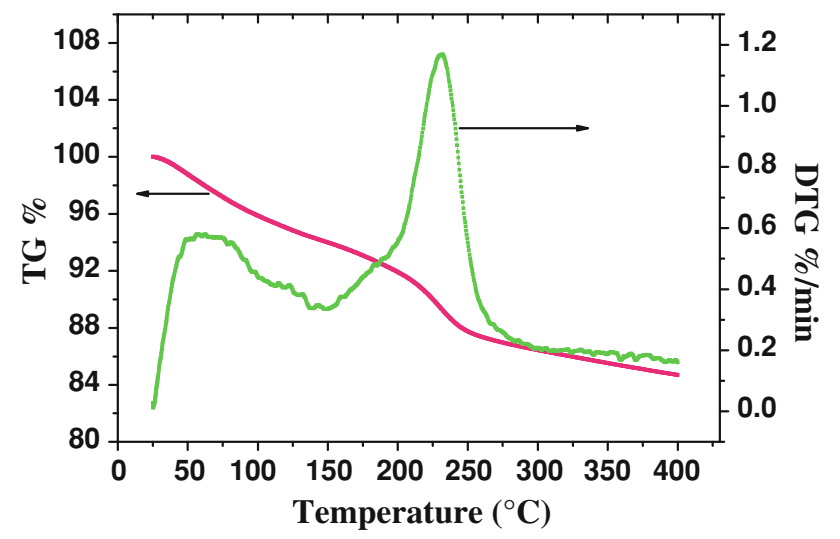

Fig. 3 TG/DTG curves of the prepared $\mathrm{His}-\mathrm{Co}_{3} \mathrm{O}_{4}$ sample

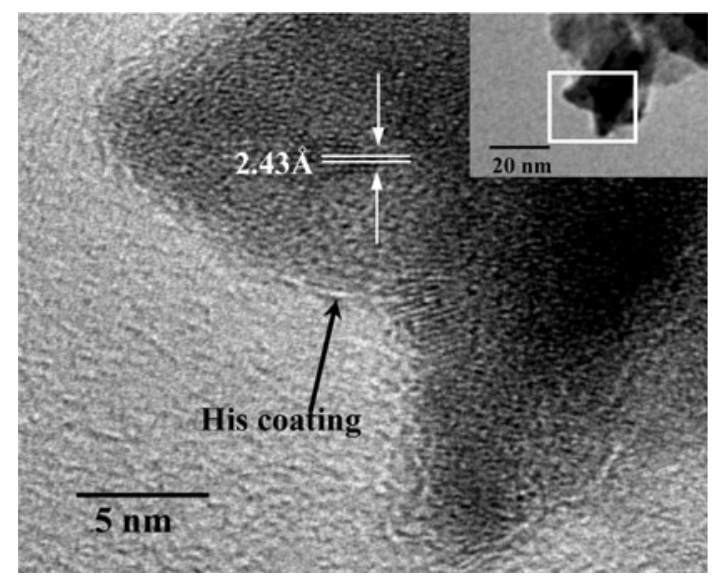

Fig. 4 HRTEM images of the $\mathrm{Co}_{3} \mathrm{O}_{4}$ particles. The samples are coated with His layers (marked with black arrows)

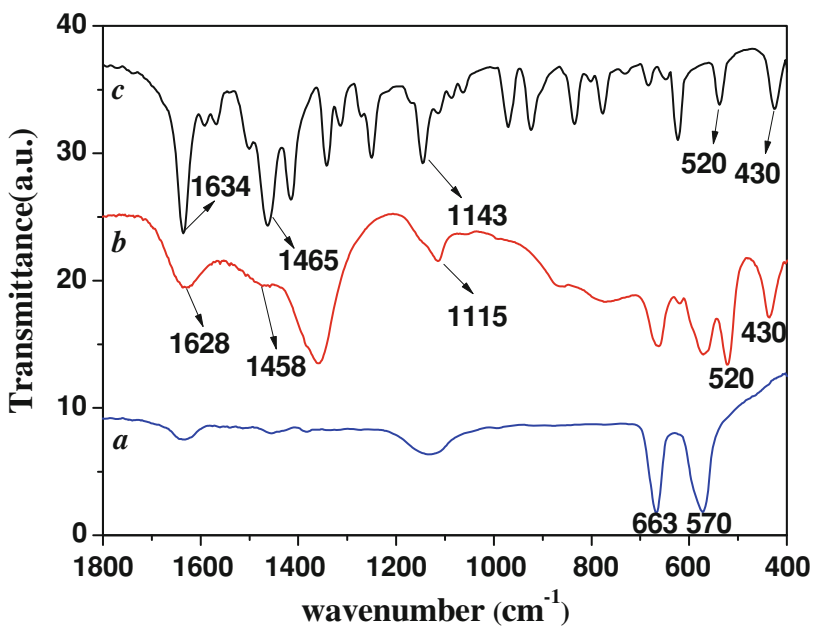

Fig. 5 FT-IR absorption spectra of a the pure $\mathrm{Co}_{3} \mathrm{O}_{4}$ NPs, $\mathbf{b}$ the prepared His- $\mathrm{Co}_{3} \mathrm{O}_{4}$ and c Histidine

spinel phase. The absorption bands (curve $b$ ) at about 1,634, 1,465 and $1,115 \mathrm{~cm}^{-1}$ are assigned to the vibration of amide I, amide II and carbon nitrogen bond $(\mathrm{C}-\mathrm{N})$ vibration of ligand His, respectively. In comparison, these three bands are present at $1,634,1,465$ and $1,143 \mathrm{~cm}^{-1}$ in pure His (curve $c$ ). The bands at 430 and $520 \mathrm{~cm}^{-1}$ in curve $b$ and $c$ are assigned to the deformation vibration of $\mathrm{C}-\mathrm{N}$ bond [36], which are not present in curve $a$ because His molecules are decomposed after sintering. The shift at these characteristic bands indicated that the surface of primary cobalt oxide NPs conjugated with the His molecules.

In order to verify the effect of His and ethanol in the synthesis process, we measured UV absorption of reaction solution. Figure 6 shows a series of spectra of cobalt nitrate $(0.1 \mathrm{~mol} / \mathrm{L})$ and $\mathrm{His}(0.5 \mathrm{mg} / \mathrm{mL})$ in water and ethanol solvent, respectively. In the test, His is added into ethanol solution of cobalt nitrate and stirred for $3 \mathrm{~h}$ and kept for $24 \mathrm{~h}$. From the curve $a$ and $b$ we can clearly see that cobalt 


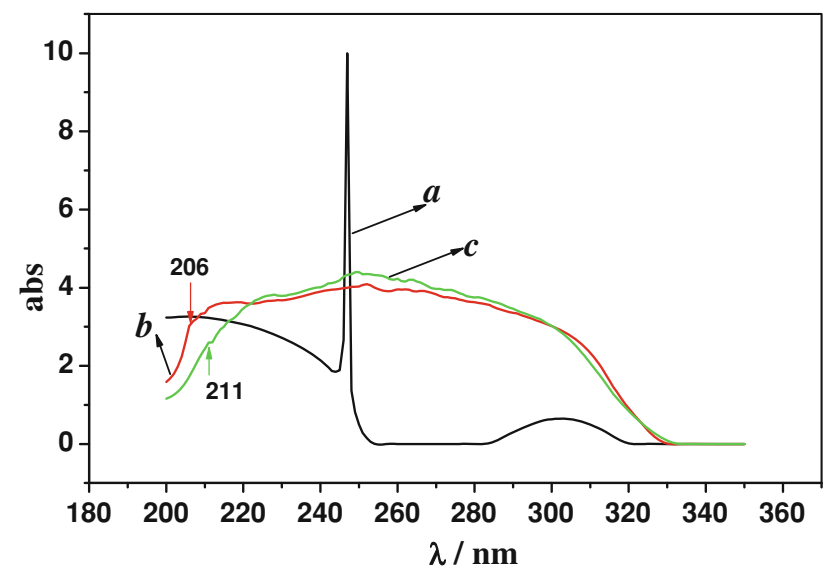

Fig. 6 The UV spectra of a cobalt nitrate in water. b Cobalt nitrate in ethanol. c Cobalt nitrate and histidine in ethanol

nitrate-ethanol could lead to broad absorption from 200 to $330 \mathrm{~nm}$, especially that there is a sharp peak of $248 \mathrm{~nm}$ in the curve $a$. However, the coordination effect of ethoxy from ethanol molecules leads to the absorption red shift from 248 to $253 \mathrm{~nm}$ and the weaker cobalt nitrate absorption. According to experimental results and previous studies [37], the shoulder peak at about $206 \mathrm{~nm}$ belongs to $n \rightarrow \sigma^{*}$ transition of hydroxyl in ethanol molecules. The intensity of this characteristic peak is decreased and slight red shift occurs from 206 to $211 \mathrm{~nm}$ with adding His, indicating that the His molecules also coordinate with cobalt ion to change electronic energy levels of ethanol molecules. Based on the tests results, the reaction mechanism between His and $\mathrm{Co}^{2+}$ in ethanol could be considered as follows. The dispersed His plays a role of crystallization sites for cobalt oxide in the precipitation, and could reduce the crystal size during a slow synthesis process [38-41]. The occurrence of coordination between ethoxy and cobalt ions in ethanol promotes further ionization of $\mathrm{H}^{+}$and the decrease of the $\mathrm{pH}$ value of solution (the $\mathrm{pH}$ of different system is shown in Table 1), which is in favor of the oxidation of nitrate group. The possible coordination structure in solution is shown in Scheme 1 (the red part is imidazole) based on the previous studies [42, 43] and this case. Nitrate group may also coordinate with cobalt ion to lead to enter into cobalt hydroxide crystal lattice. Trivalent cobalt emerged due to oxidation of nitrate group. Reduced products nitrite can easily separate from the lattice, and then spinel cobalt oxide formed after dehydration.

Table 1 The $\mathrm{pH}$ value of different system $\left(0.1 \mathrm{~mol} / \mathrm{L} \mathrm{Co}^{2+}\right.$, $0.5 \mathrm{mg} / \mathrm{mL}$ His.)

\begin{tabular}{lllll}
\hline Components & $\begin{array}{l}\text { Cobalt nitrate } \\
\text { (ethanol) }\end{array}$ & $\begin{array}{l}\text { Cobalt nitrate } \\
\text { (water) }\end{array}$ & $\begin{array}{l}\text { His } \\
\text { (water) }\end{array}$ & Ethanol \\
\hline $\mathrm{pH}$ & 2.64 & 5.30 & 7.75 & 4.65 \\
\hline
\end{tabular}

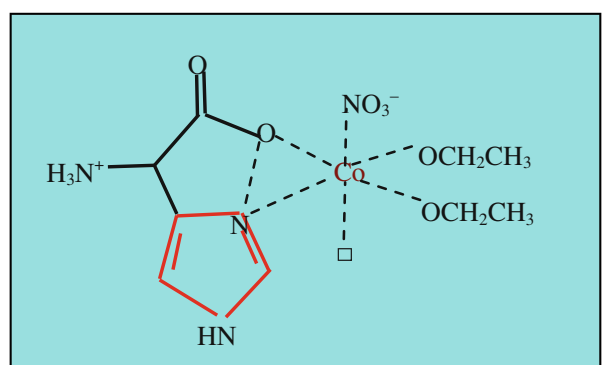

Scheme 1 The possible structure of coordination compound, the square symbol is empty electronic orbit of Co ion

The synthesis of $\mathrm{Co}_{3} \mathrm{O}_{4}$ in the reaction system can be given by the following Equations.

$$
\begin{aligned}
\mathrm{Co}^{2+}+\mathrm{NO}_{3}^{-}+\mathrm{H}^{+} & \rightarrow \mathrm{Co}^{3+}+\mathrm{NO}_{2}^{-}+\mathrm{OH}^{-} \\
\mathrm{Co}^{2+}+\mathrm{Co}^{3+}+\mathrm{OH}^{--} & \rightarrow \mathrm{Co}(\mathrm{OH})_{2}+\mathrm{Co}(\mathrm{OH})_{3} \\
& \rightarrow \mathrm{Co}_{3} \mathrm{O}_{4}+\mathrm{H}_{2} \mathrm{O}
\end{aligned}
$$

Based on these above results, the proposed formation mechanism of His- $\mathrm{Co}_{3} \mathrm{O}_{4}$ NPs is shown as Scheme 2. Step (a), cobalt hydroxide gel was formed after the hydrolysis of $\mathrm{Co}^{2+}$. During the dehydration and oxidation of $\mathrm{NO}_{3}{ }^{-}$, some cobalt hydroxide sol were changed into primary crystalline nucleus linked by His, which was the most active area due to high percentage of dangling bonds. These primary-cube units grew along with His sites into irregular cube structure, and these crystals would be the nucleus for growth of $\mathrm{Co}_{3} \mathrm{O}_{4}$ NPs. Step $b$, these primary crystals coated by hydroxide

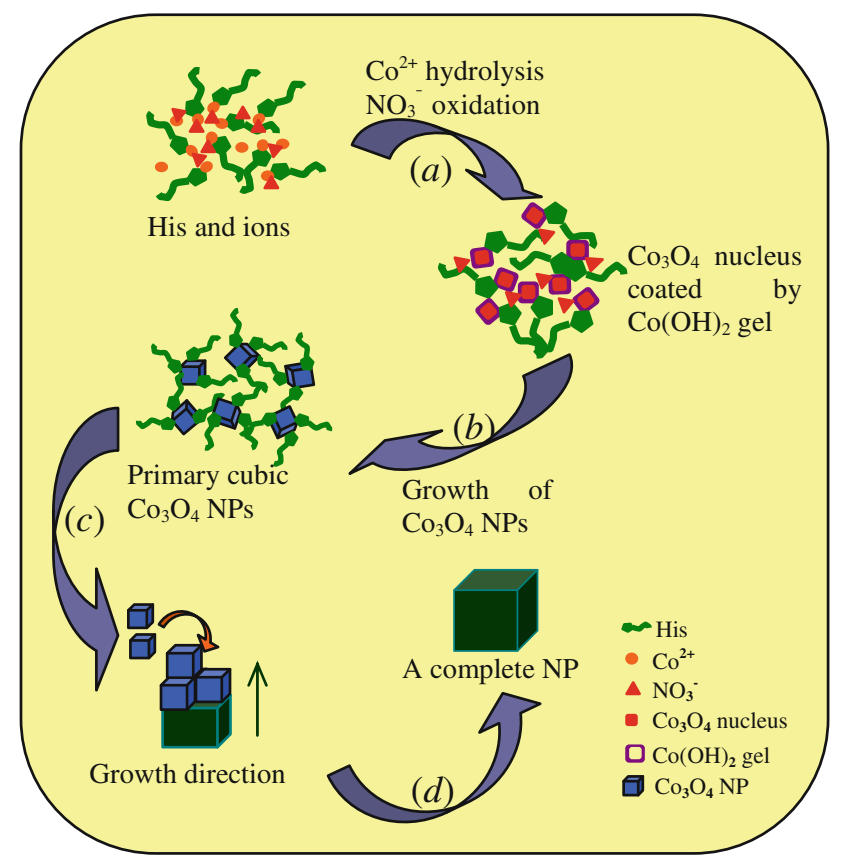

Scheme 2 The formation schematics of different steps of $\mathrm{Co}_{3} \mathrm{O}_{4}$ NPs: a $\mathrm{Co}_{3} \mathrm{O}_{4}$ nucleus formed, b Primary crystal grew by His, c Crystals began to coalesce, $\mathbf{d}$ A complete NP results 
groups maintain to grow up along their surfaces. Step $c$, these crystals aggregated into larger particles with some cubic defects. Step $d$, the aggregates further fused together to form a complete crystal (seen in Fig. 2a). Thus, many large cubic $\mathrm{Co}_{3} \mathrm{O}_{4}$ NPs were formed during the synthesis process and growth of particles.

Figure 7 shows the dependence of magnetization on applied magnetic field (M-H loop) for the synthesized $\mathrm{Co}_{3} \mathrm{O}_{4}$ NPs. The sample shows clear hysteresis loop for paramagnetic $\mathrm{Co}_{3} \mathrm{O}_{4}$ nanocrystals with coercivity $28.845 \mathrm{G}$ and saturation magnetization $2.882 \mathrm{emu} / \mathrm{g}$. The remanent magnetization of NPs is almost zero, which shows a very small particle size and superparamagnetic nature. This nature of the prepared nanoparticles will be benefit for the application of $\mathrm{Co}_{3} \mathrm{O}_{4}$ in the biomedical field [3].

In order to illustrate the toxicity of $\mathrm{Co}_{3} \mathrm{O}_{4} \mathrm{NPs}$, bacteriological tests were conducted on E. coli. The images of $E$. coli incubated in LB media in the presence of 0 and $1.25 \mathrm{mg} / \mathrm{mL} \mathrm{Co}_{3} \mathrm{O}_{4}$ fluids are shown in Fig. 8. The biocidal effect of this nano material on E. coli is given in Fig. 9. Data are expressed by $\mathrm{CFU}$ means \pm standard deviations. The concentration of $\mathrm{Co}_{3} \mathrm{O}_{4}$ NPs was changed from 2.5 to $0.1 \mathrm{mg} / \mathrm{mL}$. The control experiments were used pure $\mathrm{Co}_{3} \mathrm{O}_{4}$ NPs that is not conjugated with His. Statistical analysis was with $t$ tests method. The formula is given by [44]:

$t=\frac{\bar{X}-\mu_{0}}{S / \sqrt{n}}, \quad v=n-1$

where $\bar{X}$ is the mean of comparative sample, $\mu_{0}$ is the mean of control sample, $S$ is the standard deviations, $n$ is the sample number. The significant effect $(P<0.05)$ emerged in sample when the concentration of $\mathrm{Co}_{3} \mathrm{O}_{4}$ are $2.5 \mathrm{mg} / \mathrm{mL}$ according to the calculation results. Although the $\mathrm{Co}_{3} \mathrm{O}_{4}$ suspension with high concentration could inhibit bacterial growth, the low concentration of $\mathrm{Co}_{3} \mathrm{O}_{4}$ has no significant

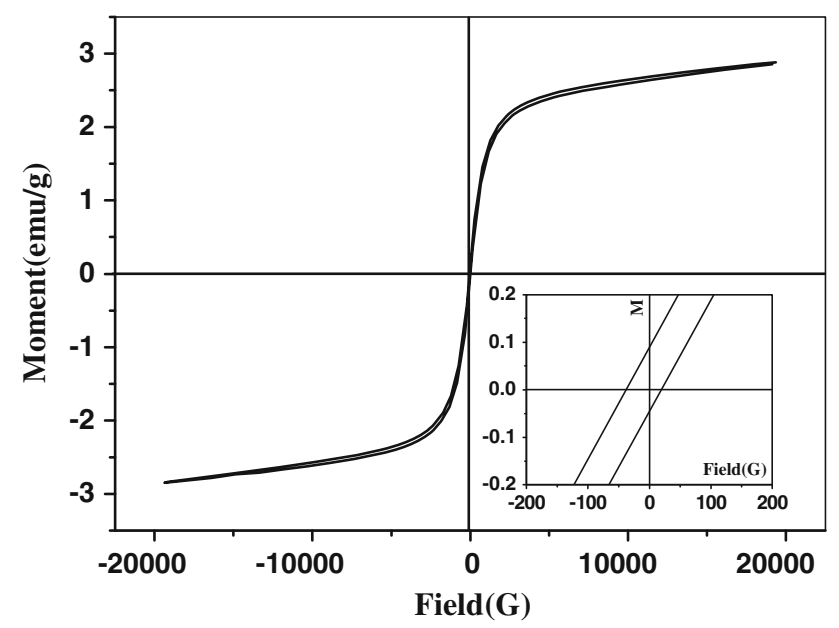

Fig. 7 The hysteresis loop of the prepared $\mathrm{Co}_{3} \mathrm{O}_{4}$ NPs, the inset shows the magnetization curve of zero field
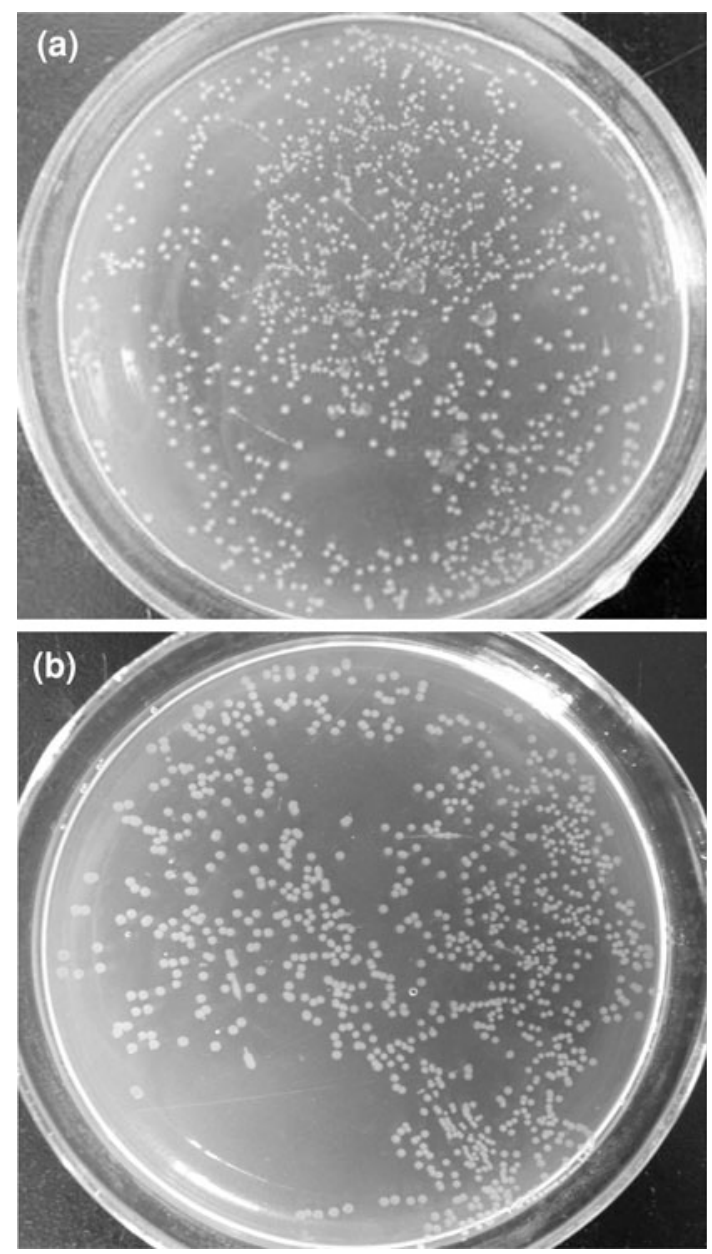

Fig. 8 The images of E. coli incubated in LB media in the presence of a $0 \mathrm{mg} / \mathrm{mL}$ and $\mathbf{b} 1.25 \mathrm{mg} / \mathrm{mL}$ His- $-\mathrm{Co}_{3} \mathrm{O}_{4}$ fluids

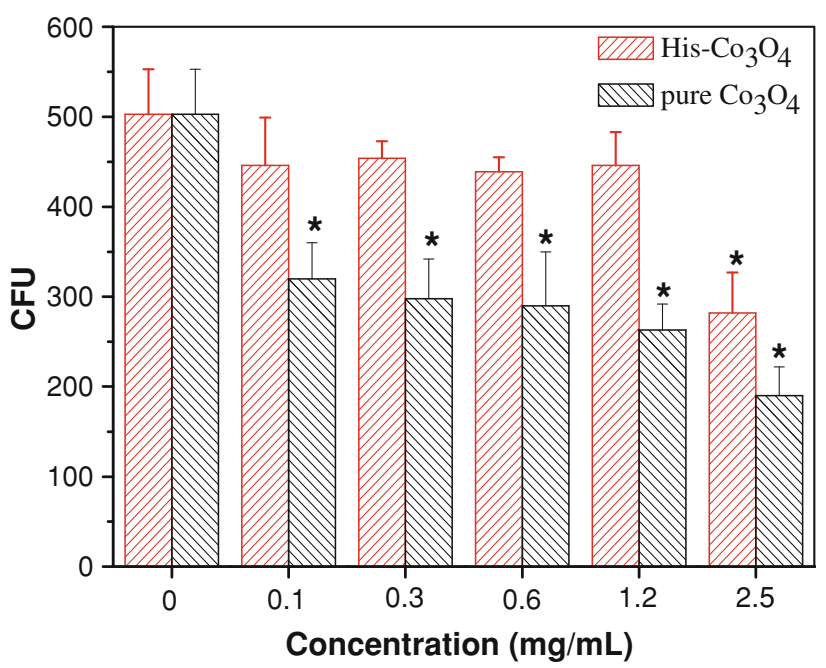

Fig. 9 CFU per plate of $E$. coli incubated in LB media in the presence of different concentrations of $\mathrm{Co}_{3} \mathrm{O}_{4}$ particles for $24 \mathrm{~h}$. Error bars indicate standard deviation. An asterisk (*) represents a significant difference 
effect on bacterial growth. Compared with the control E. Coli group incubated with pure $\mathrm{Co}_{3} \mathrm{O}_{4}$, the His- $\mathrm{Co}_{3} \mathrm{O}_{4}$ NPs we prepared possess a remarkable nontoxicity to this bacteria, indicating that the His coating layers on $\mathrm{Co}_{3} \mathrm{O}_{4}$ NPs result in good cell compatibility. The growth inhibition under high concentration maybe results from the steric effects of NPs [12, 45].

Figure 10 shows thin sections of E. coli grown in $\mathrm{Co}_{3} \mathrm{O}_{4}$ NPs $(0.6 \mathrm{mg} / \mathrm{mL})$ medium. This bacterium is a moderately sized Gram-negative bacillus that presents a tubular form. TEM image shows that there was no change in the morphology of cells and that the cell walls were not obviously damaged. An obvious result is that the NPs penetrated the cell membrane and internalized inside of $E$. coli, suggesting that the His- $\mathrm{Co}_{3} \mathrm{O}_{4}$ NPs possess a remarkable nontoxicity and good cytocompatibility for $E$. coli.

Figure 11 is given to quantify the cytotoxicity of the prepared $\mathrm{Co}_{3} \mathrm{O}_{4} \mathrm{NPs}$ and pure $\mathrm{Co}_{3} \mathrm{O}_{4}$ NPs upon L929 cell cultures. A MTT assay was performed to determine the surviving fraction in the presence of different concentrations of $\mathrm{Co}_{3} \mathrm{O}_{4}$ suspensions. Figure 10a indicates that no significant effect emerged upon $\mathrm{L} 929$ cells when $\mathrm{His}-\mathrm{Co}_{3} \mathrm{O}_{4} \mathrm{NPs}$ were used as particle suspension. $0.25 \mathrm{mg} / \mathrm{mL}$ suspension could slightly restrain cell proliferation of L929 cells, but these effects were not significant enough for any conclusion to be drawn. In the treatments of low concentrations ( 20 and $4 \mu \mathrm{g} / \mathrm{mL}$ ), L929 cells showed good resistance to the cytotoxicity of $\mathrm{Co}_{3} \mathrm{O}_{4}$ NPs. Instead, much significant effect was shown in Fig. $10 \mathrm{~b}$ indicating that the pure $\mathrm{Co}_{3} \mathrm{O}_{4}$ NPs could result in certain damage of L929 cells.

In the current study, cobalt ions are well known to generate ROS [46], and oxidize proteins [47], and have been reported to generate free radical damage in bronchoalveolar lavage fluids of rats [48]. Moreover, it is clear from our MTT results that L929 cells exposed to pure $\mathrm{Co}_{3} \mathrm{O}_{4}$ also displayed a high damage level while the His$\mathrm{Co}_{3} \mathrm{O}_{4}$ NPs generate much lower cell damage. From these

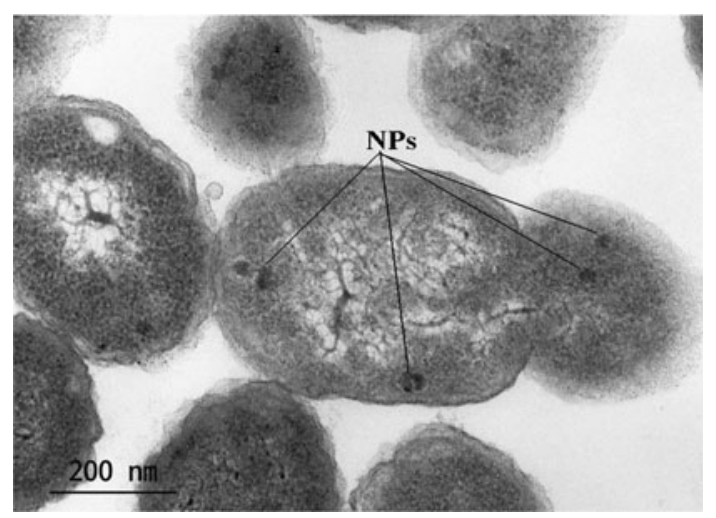

Fig. 10 TEM micrographs of E. coli thin sections with $\mathrm{His}-\mathrm{Co}_{3} \mathrm{O}_{4}$ NPs $(0.6 \mathrm{mg} / \mathrm{mL})$ internalization
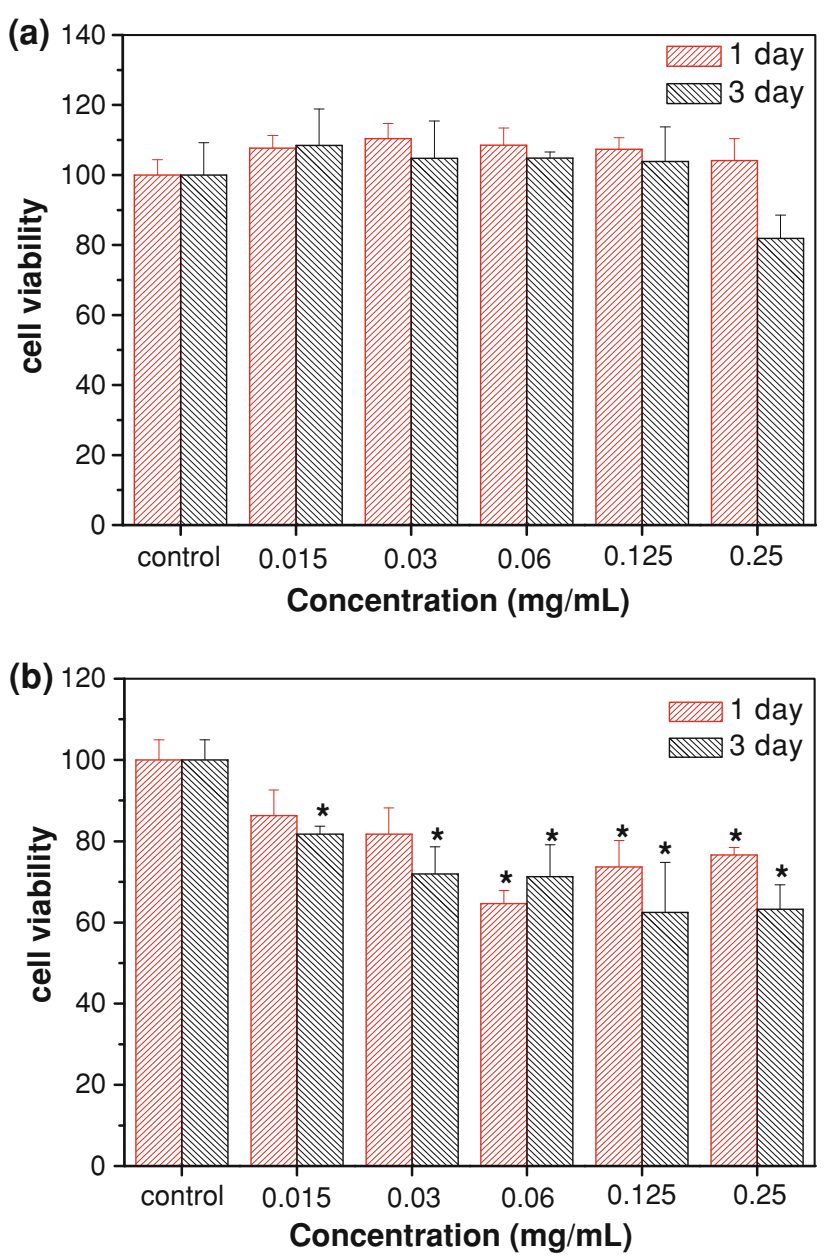

Fig. 11 Cell viability of L929 cells incubated with different concentrations of a His- $\mathrm{Co}_{3} \mathrm{O}_{4}$ NPs and b pure $\mathrm{Co}_{3} \mathrm{O}_{4}$ NPs suspensions. Error bars indicate standard deviation. * represents significant difference

results we could believe that the $\mathrm{Co}_{3} \mathrm{O}_{4}$ NPs coated with His molecules can enter into the cells smoothly, although alkaline compounds could dissolve the external part of the cell membrane [49]. On the other hand, it was reported that His structure because of the $\mathrm{C}-\mathrm{O}$ bonds and $-\mathrm{OH}$ groups may be metabolized by cell [50]. Obviously, the His molecules could promote cell growth after their metabolization. So the NPs prepared here can be surrounded within cells and shows a cytocompatibility. On the basis of their small sizes, good magnetism and cytocompatibility, the His-assisted synthesis $\mathrm{Co}_{3} \mathrm{O}_{4}$ NPs would be applied as a new types of analytical tools in biomedical fields, such as magnetic carrier, contrast agents and cells label.

\section{Conclusions}

In this paper we have successfully synthesized magnetic $\mathrm{Co}_{3} \mathrm{O}_{4}$ nanoparticles of small size $20-40 \mathrm{~nm}$ with the 
assistance of His at room temperature. Compared with other synthesis methods, this synthesis process is facile and environment friendly. The ethanol solvent has an important influence to the mineralized $\mathrm{Co}_{3} \mathrm{O}_{4}$ particles. Many cubelike NPs were well crystallized and His molecules were conjugated onto their surface during the synthesis process. VSM test shows a strong magnetic property and almost superparamagnetic nature. Bacterial experiments and $\mathrm{L} 929$ cells viability test with $\mathrm{His}-\mathrm{Co}_{3} \mathrm{O}_{4}$ particles presented good biocompatibility when their concentration were less than $1.2 \mathrm{mg} / \mathrm{mL}$ and less than $0.25 \mathrm{mg} / \mathrm{mL}$, respectively. Based on these biocompatibility and magnetism, their possible application in biomedical fields could be envisioned in the future.

Acknowledgments This work has been supported by the National Natural Science Foundation of China (project No. 60871062). The supports of Sichuan Province through a Science Fund for Distinguished Young Scholars of Sichuan Province (08ZQ026-007) and Key Technologies Research and Development Program of Sichuan Province (2008SZ0021 and 2006Z08-001-1) are also acknowledged with gratitude. We thank Analytical \& Testing Center, Sichuan University for the assistance with the microscopy work.

Open Access This article is distributed under the terms of the Creative Commons Attribution Noncommercial License which permits any noncommercial use, distribution, and reproduction in any medium, provided the original author(s) and source are credited.

\section{References}

1. A.K. Nicholas, O.W. Jessica, M.L. Charles, Adv. Mater. 21, 3970 (2009)

2. Z.L. Liu, H.B. Wang, Q.H. Lu, G.H. Du, L. Peng, Y.Q. Du, S.M. Zhang, K.L. Yao, J. Magn. Magn. Mater. 283, 258 (2004)

3. C. Adam, W. Chris, Trends Biotech. 19, 97 (2001)

4. K.G. Ajay, G. Mona, J. Biomater. 26, 3995 (2005)

5. D.T. Nguyen, D.J. Kim, K.S. Kim, Micron 42, 207 (2010)

6. X.K. Yan, L.S. Zhu, J.C. Dong, J. Funct. Polym. 1, 128 (1997)

7. Y. Xia, P. Yang, Y. Sun, Y. Wu, B. Mayers, B. Gates, Y. Yin, F. Kim, H. Yan, Adv. Mater. 15, 353 (2003)

8. H. Lin, H. Sakamoto, W.S. Seo, K. Kuwabara, K. Koumoto, J. Cryst. Growth 192, 250 (1998)

9. A.D. Sean, D. Erik, M. Stephen, Curr. Opin. Solid State Mater. Sci. 7, 273 (2003)

10. J.M. Ouyang, Prog. Chem. 17, 749 (2005)

11. T.X. Fan, S.K. Chow, D. Zhang, Prog. Mater. Sci. 54, 542 (2009)

12. D.H. Yan, G.F. Yin, Z.B. Huang, M. Yang, X.M. Liao, Y.Q. Kang, Y.D. Yao, B.Q. Hao, D. Han, J. Phys. Chem. B 113, 6047 (2009)

13. D.H. Yan, G.F. Yin, Z.B. Huang, X.M. Liao, Y.Q. Kang, Y.D. Yao, B.Q. Hao, J.W. Gu, D. Han, Inorg. Chem. 48, 6471 (2009)

14. Z.G. Liu, Y.G. Zu, Y.J. Fu, R.H. Meng, S.L. Guo, Z.M. Xing, S.G. Tan, Colloids Surf. B Biointerfaces 76, 311 (2010)
15. G.X. Wang, Y. Chen, K. Konstantinov, M. Lindsay, H.K. Liu, S.X. Dou, J Power Sources 109, 142 (2002)

16. K. Guo, A.H. Jayatissa, Mater. Sci. Eng. C 28, 1556 (2008)

17. S.R. Ahmed, P. Kofinas, J. Magn. Magn. Mater. 288, 219 (2005)

18. A. Salimi, R. Hallaj, H. Mamkhezri, S.M.T. Hosaini, J. Electroanal. Chem. 619, 31 (2008)

19. L.B. Ornstein, Physics of non-tetrahedrally bonded binary compounds (Springer, New York, 1984), p. 17

20. W.Y. Li, L.N. Xu, J. Chen, Adv. Funct. Mater. 15, 851 (2005)

21. X.D. Lou, J. Han, W.F. Chu, X.F. Wang, Q.T. Cheng, Mater. Sci. Eng. B 37, 268 (2007)

22. X.H. Xia, J.P. Tu, J. Zhang, J.Y. Xiang, X.L. Wang, X.B. Zhao, Sol. Energy Mater. Sol. Cells 94, 386 (2010)

23. J. Wollenstein, M. Burgmair, G. Plescher, T. Sulima, J. Hildenbrand, H. Bottner, Sens. Actuators B 93, 442 (2003)

24. N.R. Jana, Y.F. Chen, X.G. Peng, Chem. Mater. 16, 3931 (2004)

25. C. Nethravathi, S. Sen, N. Ravishankar, M. Rajamathi, C. Pietzonka, B. Harbrecht, J. Phys. Chem. B 109, 1146 (2005)

26. G.A. El-Shobaky, T. El-Nabarawy, I.F. Hewaidy, Surf. Technol. 10, 225 (1980)

27. L. Hu, Z.H. Liu, Mater. Sci. Eng. Powder Metall. 13, 195 (2008)

28. P. Dutta, M.S. Seehra, S. Thota, J. Kumar, J. Phys. Condens. Matter. 20, 152 (2008)

29. A.M. Cao, J.S. Hu, H.P. Liang, W.G. Sang, L.J. Wan, J. Phys. Chem. B 110, 58 (2006)

30. P. Jinsoo, X.P. Shen, G.X. Wang, Sens. Actuators B Chem. 136, 494 (2009)

31. Y.C. Chen, Y.G. Zhang, S.Q. Fu, Mater. Lett. 61, 701 (2007)

32. A. Morsali, H.H. Monfared, A. Morsali, J. Mol. Struct. 938, 10 (2009)

33. G. Wang, X. Shen, J. Horvat, B. Wang, H. Liu, D. Wexler, J. Phys. Chem. C 113, 57 (2009)

34. Y. Osamu, Int. J. Inorg. Mater. 3, 643 (2001)

35. B. Roberta, F.L. Roselyne, B. Nicolas, D. Shakib, F.B. Marc, F. Fernand, Nano Lett. 6, 866 (2006)

36. Q. Hu, G.Y. Wang, G. Liu, J.M. Ou, R.L. Wang, Spectrosc. Spectral Anal. 30, 192 (2010)

37. R.M. Silverstein, G.C. Bassler, T. C. Morrill, Spectrometric identification of organic compounds (Wiley, 1981), vol 4

38. R.R. Naik, S.J. Stringer, G. Agarwal, S.E. Jones, M.O. Stone, Nat. Mater. 1, 169 (2002)

39. B.D. Matthew, R.N. Rajesh, O.S. Morley, C. Ye, H.S. Kenneth, Chem. Commun. 53, 1776 (2004)

40. S.K. Lee, D.S. Yun, A.M. Belcher, Biomacromolecules 7, 14 (2006)

41. H.X. Liu, B.B. Huang, Z.Y. Wang, X.Y. Qin, X.Y. Zhang, J.Y. Wei, P. Wang, M.H. Whangbo, J. Alloys Compd. 507, 326 (2010)

42. B.O. David, C. Gerald, R. Nagaraja, B. Nick, L. Edward, Eur. J. Biochem. 268, 42 (2001)

43. P. Deschamps, Coord. Chem. Rev. 249, 895 (2005)

44. M.J. Campbell, M. David, Medical statistics: a commonsense approach (Wiley, 1999), vol 1, p. 18

45. Z.B. Huang, X. Zheng, D.H. Yan, G.F. Yin, X.M. Liao, Y.Q. Kang, Y.D. Yao, D. Huang, B.Q. Hao, Langmuir 24, 4140 (2008)

46. W.G. Zou, M.D. Yan, W.J. Xu, H.R. Huo, L.Y. Sun, Z.C. Zheng, X.Y. Liu, J. Neurosci. Res. 64, 646 (2001)

47. A. Petit, F. Mwale, C. Tkaczyk, J. Antoniou, D.J. Zukor, O.L. Huk, Biomaterials 26, 4416 (2005)

48. C.A.J. Dick, D.M. Brown, K. Donaldson, V. Stone, Inhal. Toxicol. 15, 39 (2003)

49. J.E. Death, D. Coates, J. Clin. Pathol. 32, 148 (1979)

50. B.B. Donald, A.B. Lee, J. Bacteriol. 127, 1472 (1976) 